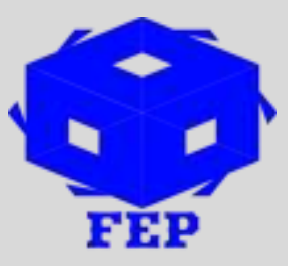

\title{
EFFECTIVENESS OF TAXPAYER EDUCATION ON TAX COMPLIANCE FOR SMALL AND MEDIUM ENTERPRISES IN KENYA: A STUDY OF SELECTED BUSINESS ENTERPRISES IN KITENGELA TOWN IN KAJIADO COUNTY \\ Robin Marita Aondo ${ }^{1}$, \\ ${ }^{1}$ The Management University of Africa, Kenya
}

*Corresponding Author: Robin Marita Aondo

Corresponding Author Email: mariitarobin@yahoo.com

Article Received: 08-05-19 Accepted: 30-05-19

Published: 10-06-19

Licensing Details: Author retains the right of this article. The article is distributed under the terms of the Creative Commons Attribution-NonCommercial 4.0 License (http://www.creativecommons.org/licences/by-nc/4.0/) which permits non-commercial use, reproduction and distribution of the work without further permission provided the original work is attributed as specified on the Journal open access page.

\begin{abstract}
This research paper aim was to establish the effectiveness of taxpayer education on tax compliance for SMEs in Kitengela town. There are reasons why KRA never met its revenue targets and the revenue collected has never surpassed the target set aside by the commission. The non-compliance of tax by SMEs can be attributed to the tax gap that is available in every fiscal year. KRA conducts taxpayer education to all registered SMEs in an effort to improve the existing level of tax compliance. The only way KRA will meet their target revenue is when they include all SMEs in the generation of the revenue. The study was anchored on Theory of Reasoned Action and Fisher Tax Compliance Model while the study variables were PAYE form of tax, tax rates, tax compliance cost, tax penalties and fines. The target population of the study were 1400 SMEs with a sample that was random stratified chosen of 140 SMEs. The data was analyzed using descriptive statistics, inferential statistics and SSPS version 24.0. The inferential statistics was employed to establish the relations that exist between the study variables. Pearson correlation matrix was used for predicting and describing the variables in terms of directions and magnitude while regression analysis was conducted at a level of 5\%. The data analysis tools will be SSPS and the use of inferential statistics. The study established that the effectiveness of taxpayer education on tax compliance and all the predictors as shown by beta coefficients: PAYE $(\beta=0.542)$; tax rates $(\beta=0.482)$ and tax penalties and fines $(\beta=0.632)$. However, the study established there is a positive but statistically insignificant relationship $(\beta=0.06, p=0.671>0.05)$ between tax
\end{abstract}


compliance cost and tax payer education. The study concluded that tax rates, PAYE, tax penalties and fines contribute greatly to tax compliance and finally tax compliance cost have the most significant influence on tax compliance. The study recommends that KRA should have an office in every county that will address tax issues at county level and the services to be offered should include tax penalties, filing of tax returns, tax computation and tax differentiation.

Keywords: Tax fines and Penalties, Tax Compliance, KRA, Tax Education,

\section{INTRODUCTION}

The Kenya Revenue Authority anniversary celebration in 2005 was the year which the Authority inaugurated and adopted the concept of Tax clinic, where taxpayers were education and training on tax matters. The establishment of taxpayer service division under the department of Support Services was to enhance effective taxpayer education and the authority established customer service desk in all KRA regions and major centers, with main aim of increasing outreach services to taxpayers. In 2008 taxpayers services was transferred to Marketing and communication division whose mandate was internal and external education. KRA designated annual taxpayers' week to coincide with national freedom heroes' day that adopted a slogan 'Kulipa Ushuru ni Kujitegemea'. Kenya Revenue Authority categorises taxpayers as small and large or medium that is determined by business or organization turnover or income. Taxpayers irrespective of their categories they are required to comply with Income Tax, Value Added Tax (VAT), Pay As You Earn (PAYE), Withholding Tax and Customs duties. Aksnes (2011) define taxpayer education as a method of educating or training people in the process of taxation and the reasons why paying tax is important. The education or training helps the taxpayers in meeting their tax obligation. The primary objective of taxpayer education is to inspire voluntary compliance among taxpayers. According to Misra (2004) the underlying aim of taxpayer education is to provide the following benefits such as changing taxpayer's attitude towards taxation, provision of knowledge on tax laws and compliance and improves tax collection through voluntary compliance.

Small and Medium Enterprises comprises over $95 \%$ of organizations in Kenya, and they are the driving force in the country economy with contributions through jobs creation, exports and imports, contributions of the GDP, stimulating competition, innovation and technical support provision to large organizations among others. The Economic Survey (2017) indicated that over $80 \%$ of jobs created in Kenya were in the SMEs Sector. In Kenya SMEs are defined by Micro and Small Enterprise Act 2012. Micro enterprises are defined as enterprises with annual turnover not exceeding Ksh 500,000 and have employees not more than 10; Small enterprise are defined as enterprises with annual turnover that falls between Ksh 500,000 to Ksh 5,000,000 and have a staff capacity between 10 to 49 while medium enterprise are defined as enterprises with annual turnover of Ksh 5,000,000 to ksh $800,000,000$ with a staff capacity of between 50 to 99 . 
In order for KRA to raise tax revenue tax education for the SMEs has become necessary and at the same time the authority recognises that achieving tax compliance especially for SMEs is not an easy task however this can reduce with proper and quality training on tax education (Kimungu \& Kileva, 2007). SMEs in Kenya shows hostilities for tax collectors on issues that are related to tax compliance just to mention a few scenarios there are several reports in Kenya media on tax evasion and sometime back there was a protest on implementation of electronic tax register. Kitengela Town has a diverse population and majority are working under the informal settlement where tax compliance is a major challenge that KRA needs to address. For the SMEs in Kitengela non-compliance may not be intentional but can be attributed to inadequate information or awareness of their tax obligations or complex nature of the tax filling system that is done online.

The expectation of tax education is that taxpayer will be in a position to understand tax laws and procedures that will create a positive attitude on tax compliance (Christina, Deborah \& Gray, 2003). SMEs in Kitengela will benefit from taxpayer education because it will provide needed information that would enable them to comply with tax issues and change their attitudes and perceptions towards tax compliance. The components of tax education are expected to handle issues that are associated with tax compliance among SMEs in Kitengela Town. The success of taxpayer education programme will be preceded by compliance by SMEs and KRA will meet their set targets of collecting tax as stipulated by the law at the minimum administrative cost.

\section{STATEMENT OF THE PROBLEM}

A nation can develop a positive tax culture when taxpayers and the revenue collection authority discharge their responsibilities. The defiant nature of taxpayers, disillusion and demotivation is always as result of inadequate understanding of the tax obligation imposed on taxpayer. Tax evasion is on the challenges that a nation faces that hampers country development (Karingi, 2005). KRA Annual report (2013) shows that authority lost ksh 108 billion that was directly attributed to the informal sector. In Kenya generally the informal sector remains untaxed and the SMEs in the sector are continuously expanding and they have the potential to bridge the deficit that is always evasive to KRA. According to Toggler (2003) a major concern issues for policy makers in emerging economies is the low levels of tax compliance. That is attributed to limited capacity of the government to collect and raise revenue for expenditure and recurrent expenses. Fjedstad and Ranker (2003) explains taxpayer education is a tool that is designed to help taxpayers to understand tax laws and procedures that involves training authority staff for provision of education, counselling and support to the taxpayer.

In 2015 Kenya Revenue Authority introduced online filling whose main aim was to broaden the tax base and to increase revenue collection. This called for training and educating taxpayers in the use of IT system for tax administration as well as increase compliances level of the taxpayer. User education has the potential to increase level of compliance especially for SMEs and they will be aware of their responsibilities as well as the sanctions that will be imposed to them if they don't comply with tax laws (Mohani, 2013). The question that Authority is yet to answer is why some SMEs don't pay tax. Most of the SMEs in Kitengela town both registered and unregistered show low tax compliance level which is a major loss of 
revenues to the central government. It's on this light that study was conducted to determine the effectiveness of taxpayer education on tax compliance for small and medium enterprises in Kitengela town in Kajiado County.

\section{STUDY HYPOTHESIS}

$\mathrm{H}_{\mathrm{o}} 1$ There is significant relationship between taxpayer education and tax compliance for small and medium enterprises in Kitengela town.

\section{THEORY OF REASONED ACTION}

Martin Fishbein and Icek Ajzen in 1980 proposed this theory. The reason way Fishbein and Ajzen introduced this theory was to enhance Anderson's theory of Information integration. The aspect of enhancement is derived from behavioral intention and the duration of preexisting human attitudes. Human intentions can predict his response which means that an individual behaviour will be affected or be influenced not only by his perceptions but also be his expectations. According to theory of Reasoned Action human behaviour and intentions are determined by three things that is personal opinion on whether a certain behavior is bad or good; favorable or otherwise; negative or positive. The individual attitude must be specific since the specificity allows the prediction in the resulting behaviour. Second the prevailing subjective social pressure from other people expectations that is individual normative beliefs or need to comply with what others expect (Ajzen \& Fishbein, 2004).

Behavioral intention is seen as the precursor that immediately leads to the actual behaviour that means that individual will react depending on the behavioral intention formed and developed. According to Theory of Reasoned Action individual actions are influenced by perceptions and attitudes and the theory recognizes that reality that attitudes indicate specific behaviour and perceived social norms may contradict it (Ogjen, 2003).

\section{FISHER TAX COMPLIANCE MODEL}

In 1986 Jackson and Milliron conducted a study on tax compliance behaviour and they identified fourteen key determinants that guide the behaviour of tax payers toward being tax compliant. These factors were divided in four structures by Fischer, Wartick, and Mark (1992). These grouping are demographic, non-compliance opportunity, attitudes and perception, the tax structure or the tax system. This model provides a framework for understanding the influence of the psychological components on taxpayer and social economic compliance decision. The Fischer model of tax compliance incorporates sociological, economic and psychological factors into a complete one (Fische, Wartick, \& Mark, 1992).

\section{TAXPAYERS EDUCATION}

The reforms in Kenyan tax system picked up the pace in 1986 when the government adopted a tax modernisation programme that was closely followed by budget rationalization programme in 1987. The main objective of the two programmes was to address widening budget deficits by establishing modalities of increasing revenue collection as well controlling government spending. Non implementation of tax laws has been characterised with corruption and political discretion in Kenya and in the late 1990s the government has been trying to reaffirm a commitment to tax reforms in order to satisfy conditional agreements with borrowers in order to maintain flow of funds (Cheeseman \& Griffiths, 2005). A study 
by Muriithi and Moyi (2006) established that tax authorities should place more emphasis on taxpayer education, tax audits and tax compliance. The complex nature of tax laws and taxpayers pay additional cost for interpretations of tax laws as well fill returns, this gives taxpayer an avenue to evade tax and this provide an avenue to provide taxpayer education. In Europe, countries like Hungary assessing taxpayer own liability and paying tax as stipulated by Hungarian tax and financial control administration is revenue collection system used in that country. The system is self-assessment and the taxpayer is required to have sufficient knowledge on tax laws and procedures. The system works fairly and treats taxpayers according to specific individual situations (Kirily, 2004).

Australia and Holland have adopted client model taxpayer system will in 2002 Pakistan have adopted an authentic taxpayer stratified segment approach that has different taxpayers, services for small, medium and large taxpayer, the main purpose is to improve voluntary compliance for each segment and the tax authority has tailor made a set of strategies each group that is appropriate for them. The strategies include law clarification, specific tax payer education initiatives and audit action (McCarctcn, 2004). The Uganda Revenue Authority has developed an awareness campaign on tax compliance through intensive taxpayer education programme that is responsible for dissemination information through workshops, seminars , radio shows, tax clinics and tax literature the is readily available in the Uganda Revenue Authority website. The URA has also adopted system that are modernised in improve on tax compliance, has minimise the cost of tax administration and has reduced compliance cost that has eventually managed to change taxpayers attitude on tax laws and procedure (Uganda Revenue Authority, 2016).

\section{TAX COMPLIANCE}

Andreoni, Erard and Feinstein (1998) define tax compliance as willingness of taxpayer to obey tax laws in order for a country to obtain its economy equilibrium. Kircler (2007) also defines tax compliance as taxpayer's willingness to pay tax with outermost honesty. Cummings (2007) defines tax evasion as the failure by taxpayer to comply with tax obligation. According to Rile (2011) tax evasion undermines revenue collection; it diminishes government mobilization of resources. According to William and Round (2009) tax penalties, inadequate understanding, high tax rates and high cost of compliances are main reasons for lading to tax evasion and fraud.. SMEs which do not comply to tax laws either unwilling or willingly. Emerging economies should ensure that tax system are efficient and effective for SMEs and don't affect them negatively. The challenge that most authorities face are poor tax system and policies. The main focus of tax policy is to make individuals and organizations to follow tax laws with convenience and trust (James \& Alley, 2004). SMEs in Kenya operates in an informal sector economic survey report 2016 indicates that the sector has semi organized and unregulated activities that are smaller.

Hall and Harvie (2003) explains that SMEs are important in a country economic development and growth in that they create jobs and build a flexible and adaptable base for competitive economy. The Economic Survey Report (2016) indicated that SMEs contribute to $70 \%$ of Gross Domestic Product in Kenya and the sector employs about $80 \%$. Doing Business in Kenya Report (2017) indicates that the legal requirement of registration of SMEs in Kenya is 
trade licenses, company registration, acquiring PIN and VAT with KRA and local authority licenses. SMEs in Kitengela Town take advantage of their small size by not declaring and submitting their tax to KRA the reason why taxpayer education is undertaken is to make them more knowledgeable on importance of remitting taxes.

\section{TAX SYSTEM FAIRNESS}

SMEs may decide not remit taxes at all due to the negative perception that tax system is unfair and they are overpaying taxes and the services that are provided by the government are not motivating. According to Porcano (2004) the significant determinant of tax payer willingness to pay tax is the perception they have on the fairness of the tax system. Richardson (2006) established in his study findings that perceived fairness plays an important role towards tax evasion. Reforms of the tax laws have turned the system into more complex and this can be another reason for tax non-compliance. The complex on tax remittance is seen on the following perspectives; the details required are too much in terms tax rules involved especially when it comes to computerised aspect of tax compliance decision. For SMEs to enhance tax compliance the rules of taxation must be simple, clear and compressive in order to make computations at their own discretion. Generally the complex nature tax system increases as the tax laws become increase with time (Richardson, 2006).

Understanding and interpreting tax laws determines SMEs ability and willingness to comply. Attitude towards complying tax laws may be possible with increasing people understanding towards tax system. In situation where SMEs develop understanding of tax system, they are more likely to develop a favourable attitude and follow tax laws (Mohd, 2010). A study by Hite and Hasseldine (2001) established that tax authority should emphasize on offering tax courses because it will impact positively on understanding on compliance.

\section{TAX RATES}

For efficiency and efficient of tax system the tax policies needs to be favouring the taxpayer. Its design should be fairly rational and their design should not directly affect the operations of SMEs and should facilitate compliance which is voluntary in nature. SMEs makes the inaccessed revenue potential and an even playing field in most of emerging economies.

\section{FINES AND PENALTIES}

Experts on taxation have a perception that the best way to increase tax incentives while other believe the best way is to increase tax penalties. In order for KRA to stop non-compliance they have to apply tax penalties effectively. The best approach is compliance is to combine various measures so as to maximize their effects on tax compliance as it were in order to move the nation from low level to higher level of tax compliance. Higher tax fines also tend to make taxpayers evade tax. Studies have shown that increasing penalties can have undesirable effects and even have more avoidance in tax remittance (Kirchler, 2007).

\section{CONCEPTUAL FRAMEWORK}




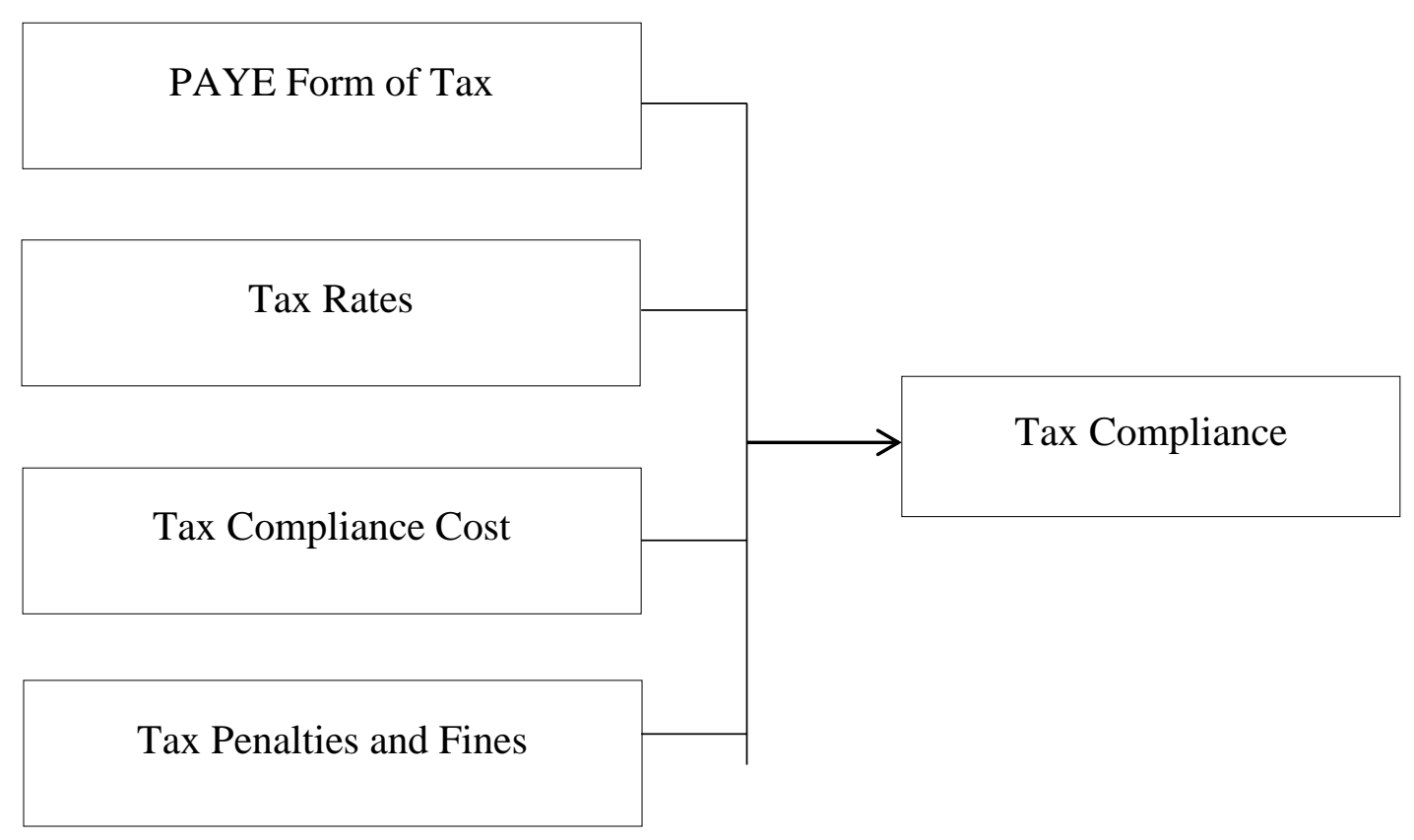

\section{RESEARCH METHODOLOGY}

The research methodology was quantitative and positivism based. The study target population was employees of SMEs located in Kitengela Township and were categorized into level of seniority in the organization from senior and middle level management and non-management staff. Data was collected using questionnaires that were deemed reasonable because of the high literacy levels among the category of employees selected to participate in the study. Semi structured questions were used to obtain general information. Questions one to five required the respondents profile and institution profile. The rest of questions were designed according to the research questions and objective. The study also used secondary sources of information for literature review. The target population of the study were 1400 SMEs with a sample size of 140 chosen through random sampling as recommended by Borg and Gall (2009).

The data was analysed using descriptive statistics, inferential statistics and SSPS version 24.0. The inferential statistics were used to show the relationship that exists between the study variables. Pearson correlation matrix was used for predicting and describing the variables in terms of directions and magnitude while regression analysis was conducted at a level of 5\%. The data analysis tools were SSPS and the use of inferential statistics and simple tabulations and presentations of the report using spread sheets. Tables were used for presenting data that was first coded and organized according to study variables from which generalizations will be made. The study used Pearson correlation matrix which will be used. The multiple linear regressions were adopted for the joint effect to research study liner relationship among the variables that will be contains a coefficient B1 for each predictor that indicates each predictor model.

The general model for predicting effectiveness of taxpayer education on tax compliance for SMEs was represented by the following model: $Y=\alpha+\beta_{1} X_{1}+\beta_{2} X_{2}+\beta_{3} X_{3} \ldots \beta n X n+\varepsilon 1$. 
Where $\mathrm{Y}$ is the dependent variable and was a linear function of $\mathrm{X}_{1} \mathrm{X}_{2} \mathrm{X}_{3} \ldots \mathrm{X}_{4}$ plus $\varepsilon 1, \alpha$ is the regression constant or intercept, $\beta_{1} \ldots \mathrm{n}$ are the regression coefficient or change induced in $\mathrm{Y}$ by each $\mathrm{X}, \mathrm{X}_{1} \ldots \mathrm{n}$ are independent variables, $\varepsilon 1$ is the error term that accounts for the variability in $\mathrm{Y}$ that cannot be explained by the linear effect of the predictor variables. To estimate model of composite index of organizational performance measure, $\boldsymbol{\alpha}$ is a regression constant or intercept, $\beta 1-3$ are the regression coefficient. EE represents the composite score of PAYE and is the independent variable. JRA represents the mediating variables composite index. The moderating variables are represented by IF which is the composite score of employee attitude and behaviour. $\varepsilon 1$ is the random error term that accounts for the viability of the challenges that cannot be explained by the linear effect of the predictor variables.

\section{RESULTS OF THE STUDY}

The dependent variable was subjected to normality via descriptive analysis and it's expected that dependent variable should produce results that have a normal distribution.

Table 1

Model summary of PAYE Pearson correlation computation

\begin{tabular}{|c|c|c|c|}
\hline $\mathrm{R}$ & R square & Adjusted R Square & Std. Error of the Estimate \\
\hline $0.347^{\mathrm{a}}$ & 0.141 & 0.136 & 4.224 \\
\hline
\end{tabular}

The regression results show that PAYE is one the training on taxpayer education on tax compliance for SMEs offered by KRA. The illustration of by regression results at $5 \%$ level of significance with beta coefficient of 12.511 and t-value of 12.589 with a P-Value of 0.000

Table 2

Model summary of tax rates Pearson correlation computation

$\mathrm{R} \quad \mathrm{R}$ square $\quad$ Adjusted R Square $\quad$ Std. Error of the Estimate

$\begin{array}{llll}0.382^{\mathrm{a}} & 0.146 & 0.142 & 4.134\end{array}$

a. Dependent variable : Tax rates

b. Predictors Taxpayer education on tax compliance for SMEs offered by KRA

The results of regression show tax rates was found to be a challenge to most SMEs and tax rates has positive influence on performance of SMEs. The regression results at $5 \%$ level of significance with unstandardized beta coefficient of 0.241 and t value of 5.579 with a $\mathrm{P}$ Value of 0.000

Table 3

Model summary of tax penalties and fines Pearson correlation computation

\begin{tabular}{cccc}
\hline $\mathrm{R}$ & $\mathrm{R}$ square & Adjusted R Square & Std. Error of the Estimate \\
$0.316^{\mathrm{a}}$ & 0.131 & 0.126 & 4.226 \\
\hline
\end{tabular}

a. Dependent variable : Tax penalties and fines

b. Predictors : Taxpayer education on tax compliance for SMEs offered by KRA 
The illustration by regression shows that beta coefficient of 0.316 and t-value of 4.226 with a $\mathrm{P}$-Value of 0.000 . The study findings indicate that tax penalties and fines is a major challenge that SMES grapples with all the time.

Table 4

\begin{tabular}{|c|c|c|c|c|c|c|}
\hline \multirow[t]{2}{*}{ Model } & & \multicolumn{2}{|c|}{ Unstandardized coefficients } & $\begin{array}{l}\text { Standard } \\
\text { coefficients }\end{array}$ & \multirow{2}{*}{$\mathrm{t}$} & \multirow{2}{*}{ Sig } \\
\hline & & $\mathrm{B}$ & $\begin{array}{l}\text { Std. } \\
\text { Error }\end{array}$ & Beta & & \\
\hline \multirow{5}{*}{1} & Constant & & 4.221 & & & \\
\hline & & 12.511 & & & 12.589 & \\
\hline & PAYE & 0.271 & 0.050 & 0.272 & 2.627 & 0.000 \\
\hline & Tax rates & 0.241 & 0.043 & 0.693 & 5.579 & 0.000 \\
\hline & Tax penalties and fines & 0.316 & 0.060 & 0.361 & 4.425 & 0.000 \\
\hline
\end{tabular}

Results in table above shows the challenges that faces SMES and all the predictors as shown by beta coefficients: PAYE $(\beta=0.271)$; tax rates $(\beta=0.241)$ and tax penalties and fines $(\beta=$ 0.316 ).

The regression equation established was as following

$\mathrm{Y}=12.511+0.271 X 1+0.241 X 2+0.316 X 3$

The implication is that PAYE, tax rates and tax penalties and fines are training offered by KRA on taxpayer education on tax compliance for SMEs in Kitengela Township. However, the study established there is a positive but statistically insignificant relationship $(\beta=0.03, \mathrm{p}=$ $0.660>0.05$ ) between tax compliance cost and tax payer education. This implies that tax compliance cost would not necessarily be affected by taxpayer education.

\section{CONCLUSION AND RECOMMENDATIONS}

The study concluded that tax rates, PAYE, tax penalties and fines contribute greatly to tax compliance and finally tax compliance cost have the most significant influence on tax compliance. Tax threshold for SMEs should be reduced to a maximum of four tax returns per year and should have a possibility of moving it towards annual or after every six months and KRA should consider simplifying returns by regularly reviewing tax laws. The study concludes that tax compliance can be influenced by provision of tax payer education on the social responsibility for paying taxes and taxpayer's intention would be to comply. There are more gains in assisting compliant taxpayers in meeting their fiscal obligation instead of spending more resources on a few non compliers. SMEs are able to understand tax obligation where there is tax benefits and tax benefits that are received in real time.

The study recommends that KRA should have an office in every county that will address tax issues at county level and the services to be offered should include tax penalties, filing of tax returns, tax computation and tax differentiation. KRA should also establish different deduction levels and apply the standard rate plan on the revenue turnover less standard 
deduction. KRA should continuously implement reforms on publicizing prosecution of noncompliant by providing incentives for voluntary compliance and the tax laws should be constantly reviewed to strengthen to seal loopholes that are being exploited by non-compliant SMEs. KRA should create more awareness on the tax compliance among SMEs through policy documentation which classify different SMEs entity.

\section{References}

Ajzen, I., \& Fishbein, M. (2004). Question raised by a reason action approach. Journal of Health ptschology vol.23 issue 4, 431- 434 .

Aksnes, F. (2014). Tax compliance, enforcement and Taxpayer eductaion . Maputo : International Centre for Tax and Development.

Azubike, J. (2009). Challenges of Tax Authorities; Tax payers in the Management of Tax reform process. Journal of Accountants vol. 1 , 323- 338.

Borg, R., \& Gall, W. (2009). Educational Research: An Introduction. New York: Flipkart Books.

Cooper, D., \& Schindler, P. S. (2011). Business research methods. New Delhi: McGraw Hill.

Fische, C. M., Wartick, M., \& Mark, M. (1992). Detection probability and taxpayer complience: A review of Literature . Journal of Accounting volume 11, 1 - 46.

Hite, P., \& Hasseldine, J. (2001). A primer on tax education in the USA. Journal of Accountant education volume 10 issue 1, 3- 13.

Kenya National Bureau of Statistics . (2016). Economic Survey 2016. Nairobi : Kenya National Bureau of Statistics .

Kircher, E. (2007). The Economic psychology of Tax behaviour . Cambridge : Cambridge University Press .

Kothari, C. R. (2004). Research Methodology. New Delhi: New Age International.

Lawan, J. U., \& Salisu, U. (2017). A review of Fischer Tax compliance model . International journal of Advanced academic reserach social and management science vol. 3 (7), 54 $-69$.

Misra, R. (2004). The impact of taxpayer education on Tax compliance . South Africa .

Mohd, R. P. (2011). Determinants of Tax compliance in Asia . Journal of social science vol.24 issue 1.

Ogjen, J. (2003). Problems with Social cognition models: a pragmatic and conceptual analysis . Journal of Health pyschology vol 22 issue 4, 424-428 .

Orodho, H. O. (2008). Elements of Education and Social Science Research Methods. Nairobi: Masola Publishers.

Porcano, T. (2004). Distributive justice and Tax policy . Journal of Accountant Review vol. $32,619-636$.

Sekaran, U. (2009). Research Methods for Business: A Skill Building Approach,. London: John Wiley \& Sons.

Williams, C. C., \& Round, J. (2009). Evaluating informal entreprenuership motives evidence from Moscow. International Journal of Entreprenuership research volume 15, 94107.

Zikmund, W. (2010). Business Research Methods . New York: McGraw-Hill Publishers. 